Life's Origin 
This page intentionally left blank 


\section{Life's Origin}

The Beginnings of Biological Evolution

Edited by

J. William Schopf 


\section{University of California Press}

Berkeley and Los Angeles, California

University of California Press, Ltd.

London, England

(C) 2002 by the Regents of the University of California

Library of Congress Cataloging-in-Publication Data

Schopf, J. William, I94I-.

Life's origin : the beginnings of biological

evolution / edited by J. William Schopf.

$$
\text { p. } \mathrm{cm} \text {. }
$$

Includes bibliographical references and index.

ISBN 0-520-23390-5 (alk. paper).-ISBN o-520-

2339I-3 (pbk. : alk. paper)

I. Life-Origin I. Title.

$\mathrm{QH}_{325 . \mathrm{L} 6942002}$

$576.8^{\prime} 3$ - de2 I

2002002071

Manufactured in the United States of America

$\begin{array}{llllllllll}10 & 09 & 08 & 07 & 06 & 05 & 04 & 03 & 02 & \text { OI }\end{array}$

I0 $\quad 9 \begin{array}{lllllllll} & 8 & 7 & 6 & 5 & 4 & 3 & 2 & \text { I }\end{array}$

The paper used in this publication meets the minimum requirements of ANSI/NISO Z39.48-1992

(R 1997) (Permanence of Paper). 